Fayetteville State University

DigitalCommons@Fayetteville State University

Social Work Faculty Working Papers

Social Work

April 2006

\title{
Mentorship and the Female College President
}

Terri Moore-Brown

Fayetteville State Universiy, tmbrown@uncfsu.edu

Follow this and additional works at: https://digitalcommons.uncfsu.edu/swk_faculty_wp

\section{Recommended Citation}

Moore-Brown, Terri, "Mentorship and the Female College President" (2006). Social Work Faculty Working Papers. 1.

https://digitalcommons.uncfsu.edu/swk_faculty_wp/1

This Article is brought to you for free and open access by the Social Work at DigitalCommons@Fayetteville State University. It has been accepted for inclusion in Social Work Faculty Working Papers by an authorized administrator of DigitalCommons@Fayetteville State University. For more information, please contact dballar5@uncfsu.edu. 


\title{
Mentorship and the Female College President
}

\author{
Terri Moore Brown ${ }^{1,2}$
}

Despite the increase in the number of women college presidents, the percentage of female college presidents is disproportionately low. Results of some studies imply that mentorship is one factor that facilitates women's climb up the administrative ladder to the college presidency. This study was designed to examine mentoring relationships among female college presidents. A sample of 91 female presidents at selected independent colleges was surveyed about mentor and mentee relationships and demographics. Findings demonstrate that a majority of the respondents had primary mentors $(56 \%)$ and also served as mentors $(64.4 \%)$ to others. Mentorship and multiple mentoring relationships are invaluable in advancing women through the ranks of higher education administration and for increasing the number of female college presidents.

KEY WORDS: mentoring; administrative ladder; career paths; female college presidents; independent colleges.

Over the past two decades, the percentage of female college presidents has increased, yet their numbers remain disproportionately low (Aisenberg \& Harrington, 1988; Brown, Ummersen, \& Sturnick, 2001; Corrigan, 2002; Edson, 1988; Green, 1986; Ross \& Green, 2000; Touchton \& Ingram, 1995). Research consistently supports the view that mentorship is a significant contributor to career development in higher education (Cullen \& Luna, 1993; Nies \& Wolverton, 2000; Queralt, 1982; Ragins \& Cotton, 1993; Scanlon, 1997; Shults, 2001). The positive impact of mentorship on career development is further confirmed by a plethora of studies on mentoring relationships across disciplines, such as business, education, and psychology (Wilson, 2001).

One theoretical framework that provides the foundation for understanding mentoring relationships is the exchange theory. There is a wide consensus among researchers that mentorship is an exchange of behaviors that are mutually benefi-

\footnotetext{
${ }^{1}$ Department of Social Work, Fayetteville State University, 1200 Murchison Road, Fayetteville, North Carolina 28301-4298.

${ }^{2}$ To whom correspondence should be addressed at Department of Social Work, Fayetteville State University, 1200 Murchison Road, Fayetteville, North Carolina 28301-4298; e-mail: tmbrown@uncfsu.edu.
}

cial to both the mentor and the mentee (Hunt \& Michael, 1983; Kram, 1985). Research suggests that antecedent factors, such as demographic characteristics, career factors, relationship factors, and types of relationships, influence the formation and maintenance of mentoring relationships. Demographic factors, including gender, age, and education, are likely to influence the mentoring exchange between mentors and mentees (Young, 2000). In relation to career development, mentors are the persons who provide guidance and support to help pave the path for mentees in achieving their career goals (Anderson \& Ramey, 1990; Braun, 1990; Daloz, 1986; Thompson, 1990).

Mentoring is an invaluable resource for the recruitment and preparation of women for the college presidency. Therefore, mentors can have a critical effect on the career paths of women who aspire to advance in higher education administration (Brown et al., 2001; Hansman, 1998; Johnson, 1998; Moore, 1982; Morrison, White, \& van Velsor, 1992; Oakes, 1999; Warner \& DeFleur, 1993). Even women with outstanding credentials can find it difficult to rise to leadership without having been vouched for by powerful individuals in leadership positions (Moore, 1982). The college presidency is 
numerically dominated by men and, as a result, men have more opportunity to know the right people and have more access to sponsorship and promotions, whereas women may be excluded from these types of exposure intentionally or unintentionally. Mentorship can help women to overcome these obstacles and to break the glass ceiling.

Sometimes women choose not to pursue top positions in higher education institutions because they believe that they must sacrifice their families, social lives, and sanity in order to be effective college presidents (Harrow, 1993). Sitting female college presidents can dispel these beliefs by serving as role models and by demonstrating how to balance personal and professional life through mentorship. Female college presidents can focus on the advantages of serving in leadership positions by discussing the accomplishments of college presidents and the roles presidents play in making a difference in higher education (Lane, 2002) and their local communities. Gardella and Haynes (2004) researched female leaders in human service agencies and found that the women perceived their families as a source of strength because they viewed their families as supportive and facilitative of their development as leaders. The women reported that they obtained knowledge, skills, and values from their families, and they gained leadership skills from both their families and their community roles.

Mentorship can help prepare aspiring female college presidents to replace those college presidents who are approaching retirement. Through mentorship, retired female college presidents can guide aspiring female college presidents (Lane, 2002). Haynes and Haynes (2004) asserted how crucial it is that women voice their opinions, help others to understand obstacles, and show appreciation for each other by realizing women's resources, strengths, and skills. They further emphasized the need for women to encourage others and move forward by building on existing successes.

Preparation for higher education administrative positions usually does not happen serendipitously. There is limited outreach to a growing pool of female faculty members with the potential to serve as college presidents but who may not have considered seeking the CEO position of a higher education institution. According to the National Center for Education Statistics (2002), the percentage of female full-time faculty members in 1992 was $33.2 \%$, by 1998 , that number had grown to $36.3 \%$, an increase of $3 \%$. Vaughan (2001) contended that leaders of higher ed- ucation institutions should consider the selection of future leaders very seriously, and they should assess the total pool of applicants on campuses, rather than limit their options to those who have decided to pursue the presidency as a career choice. Kanter (1993) asserted that women often choose occupations that have short career ladders with limited opportunities for progression, which may explain why some women do not consider pursuing college presidencies. Mentors can help these women by planting seeds that would empower them to seek college president appointments.

Maxwell (1995) emphasized the importance of leaders developing other potential leaders through mentorship by arguing there is no success without a successor. Female administrators should seek and prepare the next generation of female leaders. Women in leadership positions should take the responsibility to serve as mentors and to legitimize mentorship because they have the utmost need and the stand to gain the most (Johnson, 1998; Merriam, 1983; Moore \& Salimbene, 1980). Women should not wait for mentors to appear and offer to mentor them but, should take the initiative in seeking their own mentors (Moore \& Salimbene, 1980).

Cross-gender mentoring has been an important topic of research. Several studies demonstrate a prevalence of male administrators mentoring female administrators in higher education (Cullen \& Luna, 1993; Gillett-Karam, Smith, \& Simpson, 1997; Moore \& Salimbene, 1980; Smith, Smith, \& Markham, 2000; Vaughan, 1989). Although men are willing to mentor women, Moore and Salimbene (1980) cautioned that women should not rely on male mentors alone but should also seek female mentors. Just as it is important for women to be mentored by both men and women, women mentors should mentor both female and male mentees. Vincent and Seymour's (1995) findings from a national survey of female executive mentors indicated that women are indeed mentoring both women and men. In contrast, other studies have shown that women tend to have primarily female mentees (Ragins \& Cotton, 1993), and this finding supports a body of literature wherein researchers contend mentors tend to select mentees who are similar to themselves (Johnsrud, 1991; Moore, 1982; Queralt, 1982; Swoboda \& Millar, 1986). The results of studies indicate that cross-gender mentoring is important, but the conflicting results indicate a need for further study.

Queralt's (1982) study of the mentor's role in the career development of academic administrators and 
faculty suggested that multiple mentorships are associated with career advancement. This contention is further supported by Scanlon's (1997) synthesis of major findings in the literature concerning mentorship and female administrators in higher education; Scanlon reported that having several mentors can be valuable in facilitating a woman's climbing up the career ladder because it increases a woman's visibility among those mentors who are in leadership roles and meets her various needs. Women should choose not only several mentors but also different types of mentoring relationships (Hansman, 1998; Swoboda \& Millar, 1986). Hansman (1998) suggested that diverse mentoring relationships can address women's psychosocial, career, and personal development needs. Psychosocial mentors can enhance mentees' self-confidence and provide emotional support. Career-related mentors can provide career advice, recommend mentees for key positions, and give mentees exposure and visibility, whereas peer mentors can offer collegiality, friendship, and emotional support (Hansman, 1998; Johnson \& Huwe. 2003; Quinlan, 1999).

Ragins and Cotton's (1993) study of women's willingness to mentor showed that some women experienced drawbacks because they lacked either the qualifications or sufficient time to serve as mentors. Cullen and Luna's (1993) study of senior female mentors in higher education similarly showed that few women were available to serve as mentors because there were few senior female administrators and because many of them played a dual role of both mother and administrator, which left them little time to serve as mentors. However, some female college presidents contend that presidents have choices, and they choose either to mentor or not to mentor. It is a matter of maintaining balance among one's roles: serving as a college president, providing mentorship, and devoting time to family (Brown et al., 2001). Other senior female administrators may find that they have so many mentees that they find themselves stretched and cannot extend themselves to other women who need mentorship. Persons who do not mentor others may not know how to provide mentorship. Ragins and Cotton (1993) found that persons with prior experience in mentoring relationships, either as a mentor or mentee, are more willing to serve as mentors than are those who lack such experience.

Although there is now a well-developed body of research on mentorship across many disciplines, mentorship and the female college presidency re- mains relatively unexplored. Few studies exist partly because over previous decades there were too few female college presidents to study. Ross and Green (2000) reported that in 1986 women had a greater share of college presidencies of independent 2-year and 4-year institutions than of public institutions. By 1998 , women accounted for one-fifth or more of all college presidents of independent master's, baccalaureate, and 2-year institutions. As the percentage of female college presidents increases, it is now the appropriate time to contribute to the emerging body of literature on the female college presidency because researchers have shown that advancement to the college presidency is more likely if candidates receive mentorship (Brown et al., 2001). The present study extends the literature on female administrators in higher education by addressing mentoring relationships of female college presidents in independent colleges.

\section{Research Questions}

Existing literature suggests that mentoring and being mentored are critical career development activities that help women to advance up the academic administrative ladder (Brown et al., 2001). The intent of the present study was to describe the mentoring relationships of female college presidents. The research questions were derived in part from two prior studies of female college presidents (Buddemeier, 1998; Touchton, Shavlik, \& Davis, 1993). The following research questions were addressed: (a) Are female presidents at independent colleges engaged in mentoring relationships? (b) How many female presidents had mentors to assist their move up the administrative ladder? (c) How many presidents had more than one mentor? (d) Did female presidents actively seek their mentors or did their mentors actively seek them? (e) How many female presidents sought to be mentors to other women who desire to move up the administrative ladder? and (f) What were the relationships between demographic variables (age, total years as college president, and whether they were mentors) and female presidents who had mentors? The data collected from this study can serve as the first step in defining mentoring relationship of female presidents in independent colleges and in identifying how mentoring relationships may be used to increase the number of female college presidents. 


\section{METHOD}

Sample

The data on mentoring were drawn from a survey of female college presidents that examined career paths, mentorship, professional development, hindrances that affected their ascent to the presidency, and professional backgrounds of 91 female presidents at independent colleges. The sample was derived from the database of American Council on Education's (ACE) (1998) Office of Women in Higher Education's database. There were 129 female college presidents of 4-year independent colleges with student enrollments of 3,000 or less. Each president was mailed a cover letter, survey, self-addressed stamped envelope and coded self-addressed stamped postcard. Coded postcards, which were mailed separately from the survey, maintained respondents' anonymity and served to inform the researcher that the respondents did not need reminders. Seventy percent responded to the survey, yielding a final sample size of 91 .

\section{Instrument}

A 49-item questionnaire, made up of closeended questions that required multiple choice responses, was utilized to obtain a descriptive profile of female presidents of independent colleges and to gather data about their career paths, mentorship, professional backgrounds, and demographics. The questionnaire included portions of a research instrument used in Buddemeier's (1998) study that was derived primarily from studies by Vaughan (1989) and Vaughan and Weisman (1997). Additional content was based on the work of Faulconer (1995).

\section{RESULTS}

\section{Demographic Characteristics}

Data regarding respondents' demographic characteristics are presented in Table I. The presidents ranged in age from 40 to 73 years $(M=55.6, S D=$ 5.9). In regards to race/ethnicity, only Blacks and Whites responded to the survey; therefore they were the focus of this article. Whites comprised the majority $(95.6 \%)$ of the sample and, Blacks comprised the remainder $(4.4 \%)$. A majority of the presidents were married $(62.6 \%)$ and had children $(70.4 \%)$. The
Table I. Demographic Characteristics of Female College Presidents

\begin{tabular}{|c|c|c|}
\hline \multirow[b]{2}{*}{ Variable } & \multicolumn{2}{|c|}{ Presidents } \\
\hline & $(\%)$ & $N$ \\
\hline \multicolumn{3}{|l|}{ Age } \\
\hline Under 50 & 14.4 & 13 \\
\hline $50-59$ & 58.9 & 53 \\
\hline 60 and over & 26.7 & 24 \\
\hline \multicolumn{3}{|l|}{ Race/ethnicity } \\
\hline White, non-Hispanic & 95.6 & 87 \\
\hline Black & 4.4 & 4 \\
\hline \multicolumn{3}{|l|}{ Marital status } \\
\hline Married & 62.6 & 57 \\
\hline Divorced/separated & 11.0 & 10 \\
\hline Widowed-not remarried & 2.2 & 2 \\
\hline Single-never married & 24.2 & 22 \\
\hline \multicolumn{3}{|l|}{ Number of children } \\
\hline 0 & 29.6 & 24 \\
\hline 1 & 12.3 & 10 \\
\hline 2 & 34.6 & 28 \\
\hline 3 & 18.5 & 15 \\
\hline 4 & 1.2 & 1 \\
\hline 5 & 1.2 & 1 \\
\hline 6 & - & - \\
\hline 7 & 2.5 & 2 \\
\hline \multicolumn{3}{|l|}{ Highest educational level } \\
\hline Ph.D. & 66.7 & 60 \\
\hline Ed.D. & 17.8 & 16 \\
\hline Professional (M.D., J.D., D.D.S.) & 6.7 & 6 \\
\hline Other doctorate & 2.2 & 2 \\
\hline Master's & 5.6 & 5 \\
\hline Bachelor's & 1.1 & 1 \\
\hline \multicolumn{3}{|l|}{ Major field of study } \\
\hline Humanities/fine arts & 30.0 & 27 \\
\hline Religion/theology & 3.3 & 3 \\
\hline Social sciences & 16.7 & 15 \\
\hline Law & 2.2 & 2 \\
\hline Other & 14.4 & 13 \\
\hline
\end{tabular}

Note. $N=91 ; 1$ non-response for age, 10 non-responses for number of children, and 1 non-response for education.

number of children for the presidents ranged from 1 to $7(M=1.7, S D=1.5)$.

\section{Career Development}

Of the 91 presidents, $20.9 \%$ indicated that their mentor encouraged them to prepare and consider seeking a college president appointment. The majority $(72.5 \%)$ of presidents attended one or more professional development programs that were designed to develop or enhance skills in college administration. Of the professional development programs attended by those presidents were Harvard Educational Management (37.4\%); American Council on National Identification Program (21.2\%); 
American Council on Education Fellows $(8.1 \%)$; Bryn-Mawr College HERS (6.1\%); $8.1 \%$ attended state sponsored programs. Presidents reported that participation in these professional development programs enhanced professional skills, provided networking opportunities, enhanced self-esteem, and increased desire to seek college president appointments. Many $(63.8 \%)$ of the presidents indicated that they were nominated as candidates for their current positions or contacted by a search firm.

\section{Presidents' Relationships with Mentors}

Findings indicated that most female college presidents had a primary mentor who assisted their move up the administrative ladder. Of those who had mentors, the percentages were almost equal for mentors who had assisted the presidents directly $(53.1 \%)$ and those who had assisted the president indirectly $(46.9 \%)$. Of the 51 presidents who had primary mentors, more than one-half of the mentors were college presidents, and $43.1 \%$ were senior college administrators. More than two-thirds of the respondents' primary mentors were male $(68.6 \%)$.

More than one-half $(54.1 \%)$ of the presidents with primary mentors were in their first presidency; $57.9 \%$ of them were married, and $62.5 \%$ did not have children. Cross tabulations were conducted using the total number of presidencies held, marital status, and number of children as the independent variables and serving or not serving as a mentor as the dependent variable. A chi-square analysis showed no statistically significant relationships.

The descriptive analyses examined how college presidents' relationships were formed with their primary mentors. A majority of the presidents $(71.4 \%)$ reported that their mentors had actively sought them, whereas $28.6 \%$ of presidents had actively sought their mentors. Less than one-fourth of the respondents $(21.4 \%)$ had no mentors; the majority $(63.1 \%)$ had one to three mentors, and $15.5 \%$ had four or more mentors.

\section{Presidents' Mentoring of Others}

Of the presidents who had served as mentors, $61.9 \%$ indicated that they were in their first presidency, $69.6 \%$ reported that they were married, and $75 \%$ indicated that they had children. Additional cross tabulations were conducted using the presi- dents' total number of presidencies held, marital status, and number of children as the independent variables and serving or not serving as a mentor as the dependent variable. A chi-square analysis showed no statistically significant relationships.

The data showed that the majority of respondents $(64.4 \%, n=57)$ served as mentors. Of the respondents who were mentors, $50.8 \%$ had mentored both men and women, and $42.4 \%$ had mentored only women. Chi-square analysis indicated a significant difference between the respondent's age and whether she was mentoring others, $\chi^{2}(2, N=89)=$ $11.21, p<.001$. Older respondents were more likely than younger respondents to have served as mentors. For example, respondents between 50 and 59 years old $(73.6 \%, n=39)$ had the highest rate of having served as mentors, whereas the respondents under 50 years old $(76.9 \%, n=10)$ had the highest rate of not having served as mentors.

\section{DISCUSSION}

The purpose of this study was to assess mentoring relationships among female college presidents of selected independent colleges. The finding that a majority of college presidents in this study had received mentoring suggests that mentorship plays a critical role in advancing female college presidents up the administrative ladder. That so many of these women had been involved in mentoring relationships, either having been mentored, having served as a mentor, or both, also suggests that aspiring female college presidents recognize the value of mentorship in administrative advancement.

This study's findings regarding antecedent factors, particularly demographic factors such as age and gender, support Young's (2000) contention that demographic factors are likely to influence the mentoring exchange between mentors and mentees. For example, congruent with Vincent and Seymour's (1995) finding that female mentors were older and had more work experience than non-mentors, the older female college presidents in this study were more likely than were the younger presidents to have served as mentors.

More than half the presidents reported having one to three mentors and, in some cases, four or more mentors. These findings are consistent with those reported by Hansman (1998), Queralt (1982), Scanlon (1997), and Swoboda and Millar (1986). Consistent with Martin's (2000) suggestion that college 
presidents, especially first timers, should seek former or current sitting presidents as their mentors, more than one-half of the presidents' mentors were other college presidents. Women may be encountering fewer barriers in gaining access to mentors because nearly three-quarters of the female college presidents in this study reported that their primary mentors had actively sought them. The majority of the presidents' mentors were male, which may indicate that men are beginning to recognize the value of women in higher education administration. This finding may provide support for an issue raised by Burke and McKeen (1996) about whether women in administration can derive critical benefits from female mentors if women lack resources and influence. Could it be that male mentors who are viewed as having influence and credibility are likely to be associated with a successful climb to the college presidency?

Despite having multiple roles, such as marriage, children, and careers, female college presidents are mentoring both men and women. This finding is also noteworthy because, unlike findings from some studies (Johnsrud, 1991; Moore, 1982) that showed women primarily mentor women, the presidents in this study mentored nearly equal numbers of both men and women. After experiencing the positive benefits mentoring has had in their own career advancement, perhaps these female college presidents have come to view mentorship as an important professional responsibility. Being mentored served as an impetus for them to serve as mentors to the next generation of aspiring college presidents. In addition, this finding may indicate that female presidents make choices and blend multiple roles in a manner that promotes the professional responsibility to seek mentees and to provide mentorship.

\section{CONCLUSIONS}

The number of female college presidents is increasing. The results of the present study demonstrate the availability of female college presidents willing to serve as mentors to other women who seek the college presidency. Through mentoring, female college presidents can facilitate potential female presidents' understanding of the college presidency and empower them to attain the necessary knowledge and skills required for the position. Furthermore, as this study showed that only a small fraction of the female presidents had actively sought their mentors, female presidents may strongly en- courage aspiring female presidents to become more proactive and strategic in their career planning and pursuit of multiple mentors.

There are a few professional development programs, formal mentoring programs, and professional networks that would help women climb the career ladder. Innovative initiatives, such as list serves and e-mail relationships, may prove beneficial to aspiring female college presidents. Such electronic mentoring options, including MentorNet ACE, which offers online mentoring programs, and E-mentoring and telementoring, could possibly alleviate geographical and time constraints (Mueller, 2004).

Potential female college presidents must identify their own mentoring needs and strategize about how to provide and receive mentoring. Further study is needed on the different types of mentoring relationships that exist among female college presidents. Additional research is also needed to determine what types of mentoring relationships are most effective. Obstacles that women encounter in their mentoring relationships need identification.

Finally, there is a paucity of female college presidents who are Women of Color. Academic leaders should reflect the diversity of the students, faculty, staff, and administrators in the higher education institutions that they serve. Higher education leaders must demonstrate a concerted effort to increase the number of female college presidents through mentorship and counteract forms of inequality. Furthermore, to promote equity in higher education institutions, exploration is needed to determine how to support Women of Color through mentoring. Obstacles and inequities continue to affect Women of Color and prevent them from breaking the glass ceiling. The paucity of Women of Color in top leadership positions confirms this finding. There are few Women of Color to serve as mentors, and there is limited mentoring outreach to those who demonstrate the potential to serve as college presidents. Research is needed to determine if the mentoring needs of Women of Color are different from those of White women. Further research is also needed to explore what type of mentoring relationships, if any, Women of Color who are serving as faculty members and in managerial positions already have.

\section{REFERENCES}

Aisenberg, N., \& Harrington, M. (1988). Women of academe: Outsiders in the sacred grove. Amherst, MA: University of Massachusetts Press. 
American Council on Education. (1998, May). Women in higher education [Partial list extracted from database]. Washington, DC: Author.

Anderson, R. J., \& Ramey, P. (1990). Women in higher education: Development through administrative mentoring. In L. B. Welch (Ed.), Women in higher education: Changes and challenges (pp. 183-190). New York: Praeger.

Braun, R. (1990). The downside of mentoring. In L. B. Welch (Ed.), Women in higher education: Changes and challenges (pp. 191-198). New York: Praeger.

Brown, G., Ummersen, C. V., \& Sturnick, J. (2001). From where we sit: Women's perspectives on the presidency. Washington, DC: American Council on Education.

Buddemeier, S. D. (1998). Female community college presidents: Career paths, experiences, and perceptions of the presidency. (Doctoral dissertation, North Carolina State University, 1998). Dissertation Abstracts International, 59, 0744.

Burke, R. J., \& McKeen, C. A. (1996). Gender effects in mentoring relationships. Journal of Social Behavior and Personality, 11 91-105.

Corrigan, M. E. (2002). The American college president. Washington, DC: American Council on Education.

Cullen, D. L., \& Luna, G. (1993). Women mentoring in academe Addressing the gender gap in higher education. Gender and Education, 5, 125-138.

Daloz, L. A. (1986). Effective teaching and mentoring: Realizing the transformational power of adult learning experience. San Francisco: Jossey-Bass.

Edson, S. (1988). Pushing the limits: The female administrative aspirant. Albany, NY: State University of New York Press.

Faulconer, K. A. (1995). Women in community college administration: A two-decade progress report. Initiatives, 57(1), 1119.

Gardella, L. G., \& Haynes, K. S. (2004). A dream and a plan: $A$ woman's path to leadership in human services. Washington, DC: National Association of Social Workers Press.

Gillett-Karam, R., Smith, K. B., \& Simpson, J. (1997). Admin istrators in North Carolina community colleges: $A$ compara tive study by gender. A preliminary study. Washington, DC American Council on Education. (ERIC Document Reproduction Service No. ED409073)

Green, M. F. (1986). The American college president: A contemporary profile. Washington, DC: American Council on Education.

Hansman, C. A. (1998). Mentoring and woman's career development. In L. L. Bierema (Ed.), Women's career develop ment across the lifespan: Insights and strategies for women, or ganizations, and adult educators (pp. 63-71). San Francisco: Jossey-Bass.

Harrow, A. J. (1993). Power and politics: The leadership challenge. In P. T. Mitchell (Ed.), Cracking the wall: Women in higher ed ucation administration (pp. 142-158). Washington, DC: College and University Personnel Association.

Haynes, K. S., \& Haynes, K. E. (2004). Women's issues. In A. L Sallee (Ed.), Social work and social welfare: An introduction (pp. 287-306). Dubuque, IA: Bowers.

Hunt, D., \& Michael, C. (1983). Mentorship: A career training and development tool. Academy of Management Review, 8, 475485.

Johnson, G. G. (1998). African American women administrators as mentors: Significance and strategies. Initiatives, $58(3), 49$ 56.

Johnson, W. B., \& Huwe, J. M. (2003). Getting mentored in graduate school. Washington, DC: American Psychological Association.

Johnsrud, L. K. (1991). Administrative promotion: The power of gender. Journal of Higher Education, 62, 119-149.

Kanter, R. M. (1993). Men and women of the corporation. New York: Basic Books.
Kram, K. (1985). Mentoring at work. Glenview, IL: Scott, Foresman.

Lane, K. (2002). Moving up. Community College Week, 14(15) $3-4$.

Martin, R. (2000). All the presidents' mentors. Trusteeship, 8(5), $20-23$.

Maxwell, C. J. (1995). Developing the leaders around you. Nashville, TN: Nelson.

Merriam, S. (1983). Mentors and protégés: A critical review of the literature. Adult Education Quarterly, 33, 161-173.

Moore, D., \& Salimbene, A. (1980). The dynamics of the mentorprotégé relationship in developing women as academic lead-

Moore, K. M. (1982). What to do until the mentor arrives? Professional advancement kit. Washington, DC: National Association for Women Deans, Administrators, and Counselors. (ERIC Document Reproduction Service No. ED234296).

Morrison, A. M., White, R. P., \& Van Velsor, E. (1992). Breaking the glass ceiling: Can women reach the top of America's largest corporations? Reading, MA: Addison-Wesley.

Mueller, S. (2004). Electronic mentoring as an example for the use of information and communications technology in engineering education. European Journal of Engineering Education 29(1), 53-63.

National Center for Education Statistics. (2002). Salary, promotion, and tenure status of minority and women faculty in U.S colleges and universities. Washington, DC: U.S. Department of Education.

Nies, C., \& Wolverton, M. (2000, April). Mentoring deans. Paper presented at the annual meeting of the American Educational Research Association, New Orleans, LA. (ERIC Document Reproduction Service No. ED442446).

Oakes, J. L. (1999). Women as capable leaders in higher education administration: A historical journey with implications for professional mentoring. Leadership Journal: Women in Leadership Sharing the Vision, 3(2), 57-62.

Queralt, M. (1982, April). The role of the mentor in the career development of university faculty members and academic administrators. Paper presented at the annual meeting of the National Association for Women Deans, Administrators, and Counselors, Indianapolis, IN. (ERIC Document Reproduction Service No. ED216614).

Quinlan, K. M. (1999). Enhancing mentoring and networking of junior academic women: What, why, and how? Journal of Higher Education Policy \& Management, 21(2), 31-32.

Ragins, B. R., \& Cotton, J. L. (1993). Gender and willingness to mentor in organizations. Journal of Management, 19, 97-111.

Ross, M., \& Green, M. F. (2000). The American college president. Washington, DC: American Council on Education.

Scanlon, K. C. (1997). Mentoring women administrators: Breaking through the glass ceiling. Initiatives, 58(2), 39-59.

Shults, C. (2001). The critical impact of impending retirements on community college leadership (Research Brief Leadership Series No. 1 AACC-RB-01-5). Washington, DC: American Association of Community Colleges. (ERIC Document Reproduction Service No. ED451833).

Smith, J. W., Smith, W. J., \& Markham, S. E. (2000). Diversity issues in mentoring academic faculty. Journal of Career Development, 26, 251-262.

Swoboda, M. J., \& Millar, S. B. (1986). Networking-mentoring: Career strategy of women in academic administration. Journal of the National Association of Women Deans, Administrators, and Counselors, 50(1), 8-13.

Thompson, C. M. (1990). Mentoring among nurse-faculty. In L. B. Welch (Ed.), Women in higher education: Changes and challenges (pp. 216-222). New York: Praeger.

Touchton, J., \& Ingram, D. (1995). Women presidents in the U.S. colleges and universities: A 1995 higher education update. Washington, DC: American Council on Education. 
Touchton, J., Shavlik, D., \& Davis, L. (1993). Women in presidencies: $A$ descriptive study of women college and university presidents. Washington, DC: American Council on Education.

Vaughan, G. B. (1989). Female community college presidents. Community College Review, 17(2), 20-26.

Vaughan, G. B. (2001). Developing community college leaders for the future: Crisis or opportunity. Washington, DC: American Association of Community Colleges. (ERIC Document Reproduction Service No. ED457873)

Vaughan, G. B., \& Weisman, I. M. (1997). Community college presidents: Career and lifestyle survey. Unpublished instrument. Raleigh: North Carolina State University.
Vincent, A., \& Seymour, J. (1995). Profile of women mentors: A national survey. Society for Advanced Management Journal, $60(2), 4-11$

Warner, R., \& DeFleur, L. B. (1993). Career paths of women in higher education administration. In P. T. Mitchell (Ed.) Cracking the wall: Women in higher education administration (pp. 3-18). Washington, DC: College and University Personnel Association.

Wilson, P. F. (2001). Core virtues for the practice of mentoring. Journal of Psychology and Theology, 29(2), 121-131.

Young, A. M. (2000). The exchange relationship between mentors and protégés: The development of a framework. Human Resource Management Review, 10, 177-210. 